By IO. Io nothing was left except the arch, and between ro.ro and I I that also vanished.

The stars could be seen distinctly through the aurora. When the light was at the brightest I could see the figures and hands of a lange watch, but could not distinguish the figures one from another. Thermometer $30^{\circ} 5 \mathrm{~F}$.; Barometer $29^{\circ} 69$ inches.

Pixholme, Dorking, Surrey J. E. H. GORDON

\section{Structure of Lepidodendron}

PROFESSOR DYer has already discovered one of the many new facts with which he has yet to become familiar, and hastens, in a straightforward manner, to acknowledge the circumstance; but I must again remind him that this, along with many other facts, was described in No. 129 of the Proceedings of the Royal Society. Professor Dyer further says: "Suppose the transverse septa separating these cells absorbed, as probably cuentually they cuould haze leen, and the rows of cells become scalariform vessels." But I can assure him, as a question of fact, that these cells do not become so changed; consequently his conclusion that the central cells and the investing vessels are but parts of "one central structure" becomes negatived. The separation of these two structures increases with age instead of diminishing.

$$
\text { W. C. Wilt.ramson }
$$

\section{Encke's Comet}

IT may interest those who possess small telescopes to know that this comet is now within the range of instruments of moderate apertures. On November Io I had a very satisfactory view of it, with a $4^{\prime \prime}$ equatorial by Cooke; no signs of a nucleus were observed, but there appeared to be a slight condensation of light on the following side of the comet.

\section{Bedford, Nov. Ir}

\section{The Science and Art Department}

IN your last number there appears a letter signed "Henry Uhlgren," which, among other interesting statements, contains the following: Referring to Mr. Forster's statement in the Ilouse of Commons that there was no foundation for the report that "the Examiners after having made their reports had the papers returned to them, with an instruction to reduce the number of successful candidates, as an intination had been given by a right hon. gentleman that the amount of the Grant due upon thosc papers must be reduced 20,000l.," Mr. Uhlgren states: "But previous to that a provincial local secretary, hearing the rumour, wrote to ask the Department if it were true, and received a reply saying it was true, and that instead of the amount being $20,0 \mathrm{col}$. it was $40,000 \%$. (the Department's letter can be produced.)" Premising that the amount of the whole vote for payments to teachers on results in science (which was to be reduced by $40,000 l$.) was $26,000 l$, may I ask for the prorluction or publication of this extraordinary official letter?

\section{ECONOMICAL ALIMENTATION}

$\mathrm{I}^{\mathrm{N}}$ glancing over the recent issues of the Comptes Rendus, one cannot but fail to be struck with the practical importance of many of the communications contained therein, a large proportion of which bear special reference to the Siege of Paris. In nearly every branch of science there is some endeavour made to supplement and improve our knowledge in matters such as were then of the greatest importance, and the members of the Académie have come forward eagerly to aid, by advice and precept, in overcoming the misery of a prolonged siege. Unfortunately, but little could be done, even by such men as Fremy, Dumas, Chevreul, and others, against the insuperable difficulties which presented themselves; but nevertheless. Paris owes much to her men of science who contributed many services of value, at a time when these were most needed. The manufacture and employment of nitro-glycerine in mines and shells, were successfully accomplished at a crisis when the stock of gunpowder was running terribly short, and the supply of some other reliable explosive was rendered imperative. Hitherto nitro-glycerine had been regarded as a most dangerous combustible, liable to explode at the slightest concussion, and yet we hear of its employment in shells against the Prussians, thundered forth from guns of the heaviest calibre, without one single instance of its premature explosion being recorded. Again the question of ballooning, although not perhaps very far advanced by the deliberations of the Academie, has, at any rate, been more satisfactorily solved than at any previous period, and Paris has been certainly the first to employ these frail and romantic contrivances in a practical every-day manner, and thus to render the words, "par ballon monte" familiar to the ear as a household phrase. In matters of surgery, as in those of a sanitary nature, sound advice was not wanting, and even the abstract calling of the soldier, - the philosophy of his manner of fighting-formed the theme of much scientific discussion.

But the most interesting, perhaps, of all the subjects with which the Academie des S'ciences busied itself, was that of seeking an economical means of alimeniation for the inhabitants of Paris during the siege. Given certain limited sources of supply, a fixed amount of suitable organic matter, and the problem was how to use the same to the fullest and most profitable degree. Of sheep and oxen there was but an exceedingly limited provision in proportion to the very populous state of the city, and although corn and wine were said to be in abundance, there is no doubt the authorities were from the first sorely troubled by the vague estimates that were published of these comestibles.

As a suitable manner of economising corn, M. Gauldrée called attention to the method in vogue among the Romans of parching and bruising the grains, which in this state may be made to yield an excellent and highly nutritious soup or porridge. The corn is carefully sifted by hand, browned without charring, until it breaks when taken between the teeth, and then ground in any available mill; it is mixed with cold water, boiled for thirty minutes, and seasoned as desired. So economical was this preparation, that at the public kitchens, established in certain quarters of Paris, it was possible to dispense one portion of bouillie romaine together with a small modicum of wine for the amount of five centimes.

A proposition to manufacture artificial milk, brought forward by M. Gaudin, seems worthy of some notice. That gentleman estimated that 500,000 litres per day of milk could be prepared in Paris at an exceedingly trifling cost, which should have all the nutritious qualities of good milk, and which should, besides, be neither unpleasant of taste or smell. An emulsion at a very high temperature is made of bouillon de viande prepared from bones, fat, and gelatine, and when cold, a product is obtained resembling in taste stale milk of a cheesy flavour; the components of ordinary milk are all present, the gelatine representing the casein; fat, the butter ; and sugar, the sugar of milk. For admixture with coffee, chocolate, soup, \&c., the milk is said to be by no means disagreeable.

Many propositions were brought forward to economise the blood from the abattoir, the plan suggested by M. Gaultier of mixing it with flour in the manufacture of bread being perhaps the best and simplest, as the fibrine and albumen, so rich in nitrogen--of which the alimentary properties are well known-are in this way utilised to the highest degree. Less inviting is the proposal of M. Fud to consume he carcases of animals that died of typlus, rhinderpest, and other diseases, the flesh in these instances being, so asserts M. Fud, capable of use as food, if only cooked in a suitable manner.

More important, however, than all, is M. Fremy's attempt to bring forward osseine as an article of food. Osseine is essentially different from gelatine, which has recently been asserted by chemists-erroneously, so $M$ : Fremy thinks - to be not only unnutritious, but positively injurious to the human system. Leaving, however, the question of gelatine on one side, M. Fremy procteis to advance the qualifications of osseine as an alimentary substance. Although gelatine and osseine are isomeric, in the same way as starch and dextrine are isomeric, they 